\title{
CARBON ISOTOPE DISCRIMINATION AND YIELD OF UPLAND RICE AS AFFECTED BY DROUGHT AT FLOWERING ${ }^{1}$
}

\author{
BEATRIZ DA SILVEIRA PINHEIRO², ROGER BRIAN AUSTIN³, MARIA PEREIRA DO CARMO ${ }^{4}$ \\ and MICHAEL ALAN HALL ${ }^{5}$
}

\begin{abstract}
Field experiments involving upland rice genotypes, sown in various dates in late season, were carried out to assess the relationship of carbon isotope discrimination with grain yield and drought resistance. In each one of the three years, one trial was kept under good water availability, while other suffered water shortage for a period of 18-23 days, encompassing panicle emergence and flowering. Drought stress reduced carbon isotope discrimination measured on soluble sugars $(\Delta s)$ extracted from stem uppermost internode at the end of the imposition period, but had relatively less effect on bulk dry matter of leaves, sampled at the same period, or that of uppermost internodes and grains, sampled at harvest. The drought-induced reduction in $\Delta \mathrm{s}$ was accompanied of reduced spikelet fertility and grain yield. In the three trials subjected to drought, genotypes with the highest yield and spikelet fertility had the lowest $\Delta \mathrm{s}$. However, this relationship was weak and it was concluded that $\Delta \mathrm{s}$ is not a sufficiently reliable indicator of rice drought resistance to be useful as a screening test in breeding programs. On the other hand, grain yield and spikelet fertility of genotypes which were the soonest to reach $50 \%$ flowering within the drought imposition period, were the least adversely affected by drought. Then, timing of drought in relation to panicle emergence and to flowering appeared to be a more important cause of yield variation among genotypes than variation in $\Delta \mathrm{s}$.
\end{abstract}

Index terms: Oryza sativa, internodes, spikelets fertility.

\section{DISCRIMINAÇÃO ISOTÓPICA DE CARBONO E PRODUTIVIDADE DO ARROZ DE SEQUEIRO AFETADO POR SECA NO FLORESCIMENTO}

\begin{abstract}
RESUMO - Experimentos de campo, envolvendo genótipos de arroz de sequeiro, em várias datas de semeadura, realizadas tardiamente na estação de cultivo, foram conduzidos para investigar a relação da discriminação isotópica de carbono com a produtividade de grãos e resistência à seca. Em cada ano, um experimento foi mantido em boas condições hídricas, enquanto o outro sofreu falta de água, por período de 18-23 dias, abrangendo a emergência da panícula e florescimento. A deficiência hídrica reduziu a discriminação isotópica de carbono dos açúcares solúveis $(\Delta s)$ extraídos do último entrenó do colmo, ao final do período de estresse, causando um efeito relativamente menor sobre a matéria seca das folhas amostradas na mesma ocasião, ou dos entrenós superiores e grãos amostrados na colheita. A redução de $\Delta$ s induzida por deficiência hídrica foi acompanhada de redução da fertilidade das espiguetas e do rendimento dos grãos. Nos três experimentos submetidos a estresse hídrico, os genótipos de maior rendimento e fertilidade de espiguetas apresentaram os menores valores de $\Delta$ s. Esta relação, no entanto, foi fraca, concluindo-se, assim, que $\Delta$ s não é um indicador seguro da resistência à seca em arroz, para ser utilizado com eficiência em programas de melhoramento. Por outro lado, o rendimento de grãos e a fertilidade das espiguetas dos genótipos que apresentaram o florescimento mais precocemente no período de imposição do estresse foram menos afetados pela seca. Assim, o momento de ocorrência da seca, em relação à emergência da panícula e ao florescimento, parece ser mais decisivo na determinação do rendimento de genótipos do que o $\Delta \mathrm{s}$.
\end{abstract}

Termos para indexação: Oryza sativa, deficiência hídrica, entrenós, fertilidade das espiguetas.

\footnotetext{
${ }^{1}$ Accepted for publication on September 20, 2000.

2 Agronomist, D.Sc., Embrapa-Centro Nacional de Pesquisa de Arroz e Feijão (CNPAF), Caixa Postal 179, CEP 75375-000 Santo Antônio de Goiás, GO.

E-mail: beatriz@cnpaf.embrapa.br

${ }^{3}$ Botanist, D.Sc., 15 Wingate Way, Trumpington, Cambridge
}

CB2 2HD, UK. E-mail: rbaustin@dial.pipex.com

${ }^{4}$ Biologist, M.Sc., Universidade Federal de Viçosa (UFV), Av. P.H. Holfs, s/n, CEP 36570-000 Viçosa, MG. E-mail: mpk@buynet.com.br

${ }^{5}$ Chemist, M.A., Godwin Institute, University of Cambridge, Free School Lane, Cambridge CB2 3RS, UK.

E-mail:mah2@cam.ac.uk 


\section{INTRODUCTION}

Rice is very sensitive to drought during the late stages of floral development, especially during panicle emergence and flowering (Hsiao, 1982). Yield losses resulting from water stress in this period can be severe and are associated with a decrease in spikelet fertility (Pinheiro et al., 1985). Possible reasons for this adverse effect of drought include: inhibition of the elongation of the uppermost internode resulting in panicle retention inside the flag leaf sheath (O'Toole \& Namuco, 1983); inhibition of anthesis and spikelet desiccation (Hsiao, 1982; O'Toole et al., 1984; Ekanayake et al., 1989); and pollination abnormality (Ekanayake et al., 1990).

The drought-sensitivity of rice during flowering may arise because, in contrast to leaves, rice panicles have no adaptive mechanisms to modulate their water loss. Their position in the canopy generally precludes shading by the leaves. While they possess few stomata, the diffusive conductance (mainly cuticular) of panicles is very high just after they have emerged (Batchelor \& Roberts, 1983; O’Toole et al., 1984).

Carbon isotope discrimination $(\Delta)$ of current assimilate has been shown to be negatively related to water-use efficiency (Farquhar \& Richards, 1984; Farquhar et al., 1989) and $\Delta$ has been suggested as a selection index in breeding for high yield under water limiting conditions. Dingkuhn et al. (1991) showed that under mild water stress leaf $\Delta$ was negatively correlated with leaf level water-use efficiency. However, many studies comparing different genotypes of crop species have shown that yield is often positively correlated with $\Delta$ (measured on grain or other late-formed tissue), both in the absence and in the presence of water stress (Condon et al., 1987; Craufurd et al., 1991; Ehdaie et al., 1991; Hall et al., 1994; Sayre et al., 1995; Ngugi et al., 1996). Nevertheless, under water limiting conditions negative correlations between $\Delta$ and yield have also been reported (Hall et al., 1994; Brugnoli \& Farquhar, $2000)$. One probable reason for the positive correlation in the absence of stress is that variation in $\Delta$ is associated with genotypic variation in stomatal conductance, and that high conductance, in turn, is associated with high rates of photosynthesis and, consequently, high yield. Also, in several studies where positive correlations have been found, the trials experienced terminal drought, so that late flowering genotypes which were more severely affected, had a lower yield and $\Delta$ of grain or other late-formed dry matter.

It is known from studies on wheat and barley (Austin et al., 1977, 1980) that a proportion of the carbon assimilated during the stage of inflorescence emergence accumulates in the uppermost internode (spike peduncle) as soluble carbohydrates. It has been reported by Brugnoli et al. (1998), that the $\Delta$ of soluble carbohydrates extracted from this tissue after an episode of drought during flowering and early grain filling is associated with the assimilationweighted value of the ratio of intercellular and atmospheric partial pressures of $\mathrm{CO}_{2}(\mathrm{pi} / \mathrm{pa})$, for this particular growth stage. Therefore, it would reflect the severity of the stress more sensitively than the $\Delta$ of the bulk dry matter of any plant part, sampled at the same time. Indeed, Scartazza et al. (1998), have shown the strongest correlation of these stem sugars with net assimilation rate and water use efficiency in rice. The relevance of this parameter to yield determination under drought conditions is of great interest, considering its possible application as a breeding tool.

The present study had the objective of assessing the relationship of carbon isotope discrimination of soluble carbohydrates from the uppermost internode with grain yield of upland rice genotypes, submitted to drought during panicle emergence and flowering.

\section{MATERIAL AND METHODS}

Six field trials were conducted during the period 19911994 at the research farm of Embrapa-Centro Nacional de Pesquisa de Arroz e Feijão, located at Santo Antonio de Goiás, in the state of Goiás, Brazil. This location is at latitude $16^{\circ} 28^{\prime} \mathrm{S}$, longitude $49^{\circ} 17^{\prime} \mathrm{W}$ and at an altitude of $824 \mathrm{~m}$ above mean sea level. The climate is Aw, typical of tropical Savannah regions according to the Köppen classification. It possesses two well defined seasons, a rainy season, which lasts from October to April, and a dry season, from May to September.

The soil on which all trials were conducted is a DarkRed Latosol (Typic Haplustox), originally acidic and poor in fertility, but corrected by past intensive cropping with common bean, soybean and maize, in addition to rice. 
Rice in the region is normally sown from November to December. The trials, in number of two per year, were purposely sown later in the season, starting in January, to benefit from good water availability during vegetative development but to increase the probability of drought during reproductive development. The aim was to make this stage to coincide with the onset of the dry season, in order to have a trial stressed during the critical stage of panicle emergence/flowering and a trial irrigated during this same period, to serve as a control.

All trials were of a randomized block design, with three replicates. Each plot consisted of 12 rows, spaced $0.50 \mathrm{~m}$ apart in 1991 and 1992, and $0.40 \mathrm{~m}$ apart in 1994. Plots were $5.5 \mathrm{~m}$ long in all three years. In 1991, each entry was sown on four dates, spaced one week apart. In 1992 and 1994, there were three sowing dates. The seeds were hand sown, at a rate of 80 viable seeds per $m$ of row. In each year two identical trials were sown.

There were six common entries to the trials (IAC 47, IAC 165, Rio Paranaíba, Guarani, Rio Verde and Caiapó, all belonging to the japonica group), plus a variable number of advanced breeding lines, ranging from 11 to 18 each year, including japonica and japonica $\mathrm{x}$ indica derivatives.

The sowing date was scheduled according to the growth cycle of each cultivar: early genotypes were sown two to three weeks after the late ones, to enable genotypes to be matched for date of flowering. This procedure also enabled different matched flowering dates to be obtained, thus increasing the probability of having dry weather during at least one flowering date, given the significant year to year variation in the time of onset of the dry season.

All six trials received basic fertilization and top dressing, and were kept adequately supplied of water throughout vegetative and early reproductive stages. In this period, whenever the amount of rains fell bellow potential evaporation for a four-day period, control and stressed trials were sprinkler irrigated. After the period of stress imposition, during the targeted growth stage, irrigation was resumed in the stressed trial, and maintained till grain maturation.

The 1991 trials differed in their experimental protocol due to unexpected factors. The control trial showed symptoms of iron deficiency during reproductive development and no samples were taken from it. To assess the effect of water stress, the first group of genotypes to flower in the stressed trial, which received rains at this stage of growth, were taken as non-stressed controls to compare with later sowings of the same genotypes, whose average flowering date was 15 days later and which experienced drought during this same stage. In 1992 and 1994, only the sowing dates of the control trials, corresponding to those in the stressed trials were considered.

It has to be noted that, in any one year and trial, observations and measurements were confined to one sowing of each genotype. The choice criteria were that a) the target growth stage of panicle emergence/flowering occurred when the visual symptoms of water stress (leaf rolling) were already apparent, and b) the best possible matching of flowering dates for all genotypes in the trial be attained.

The mean temperature and vapor pressure deficit at $15 \mathrm{~h}$ local time in the three year's field trials during the stress imposition period were $28.6^{\circ} \mathrm{C}$ and $19.1 \mathrm{mb}$, respectively.

Observations and measurements were taken with small differences according to trial.

For all trials, the date when $50 \%$ of the shoots in a plot had emerged panicles was recorded. From these records, the number of days from sowing to flowering, and from stress imposition to flowering (dsif) were calculated.

In the 1991 and 1992 trials, leaf water potential was measured on the last day of stress imposition, for all genotypes. In 1994, it was measured on five different days during the stress cycle, on eight genotypes. The measurements were always made during the period of maximum evaporative demand, from $12 \mathrm{~h}$ to $14 \mathrm{~h}$, using a portable pressure chamber. Six leaves per plot were excised at the collar, wrapped in aluminum foil, put into plastic envelopes and transported to the measurement site in a box containing ice. Leaves were inserted in the chamber specimen holder and pressurized till sap droplets were visible at the cut surface. This balancing pressure, taken as a negative value, was taken as a measure of water potential before leaf excision.

At the last day of the stress imposition period, 15-20 tillers, bearing fully exserted panicles of the same developmental stage, were sampled in each plot, including the control, to be extracted for ethanol soluble substances. The samples were taken to the laboratory in ice buckets. The stem uppermost internodes were chopped into small pieces and a sub-sample of $5 \mathrm{~g}$ of fresh tissue put into $50 \mathrm{~mL}$ of $90 \%$ ethanol (giving a final ethanol concentration of approximately $85 \%$ ). A week after taking the samples, an aliquot of $10 \mathrm{~mL}$ from the ethanol supernatant was transferred to a long Pyrex glass tube and evaporated in a water bath until the sample had reduced to approximately $2.5 \mathrm{~mL}$. Drying of the samples was completed in a ventilation oven at $90^{\circ} \mathrm{C}$. The tubes were then sealed. Based on experience with wheat and barley (Austin et al., 1977, 1980) the ethanol extracts were likely to have comprised mainly glucose, fructose and sucrose. For this reason, this extracted material was referred to as soluble sugars. 
Also at the end of the stress imposition period, a $10 \mathrm{~g}$ sample of flag leaf bulk tissue (1992 and 1994 trials) was taken from the studied plots of the trials. Additionally, at harvest, $10 \mathrm{~g}$ samples of uppermost internode (1991 and 1994) and grain (all three years) bulk tissue were taken. All these samples were dried and milled.

The carbon isotope composition in the samples was determined by mass spectrometry of the carbon dioxide produced by combustion of small sub-samples from each sample. Those analyses were carried out at the Laboratory of the Godwin, University of Cambridge, UK. The results were expressed in relation to the international standard, Pee Dee Belemnite. Following Farquhar \& Richards (1984), carbon isotope discrimination was expressed as deviation in parts per thousand relative to air $\mathrm{CO}_{2}$ isotopic composition ( $\Delta$ of air, taken as $-7.85 \%$ ). Values of $\Delta$ are positive and expressed as $\%$ (parts per thousand). The $\Delta$ values of the uppermost internode sugars, and that of the bulk tissue of leaves, mature uppermost internodes and grains are referred to as $\Delta \mathrm{s}, \Delta \mathrm{l}, \Delta \mathrm{p}$ and $\Delta \mathrm{g}$, respectively.

Yield $\left(\mathrm{g} \mathrm{m}^{-2}\right), 100$ grain mass $(\mathrm{g})$ and spikelet fertility $(\%)$ were determined at harvest. The yields were based on hand harvested plot areas of $2.5 \mathrm{~m}^{2}$ in 1991 and $4 \mathrm{~m}^{2}$ in 1992 and 1994, taken from the central area of each plot. Prior to harvesting, 20 panicles were collected at random from the same area, and threshed manually. The spikelets were separated into "filled grains", comprising all the caryopses which had been fertilized and had developed into grain, and "empty grains", with lemmas and paleas but no caryopses. Both fractions were counted, and spikelet fertility expressed as a percentage was calculated dividing the number of filled grains by the number of spikelets per panicle. The weight of the filled grains fraction was added to the plot grain weight fraction. The 100 grain mass (g) was estimated from six sub-samples of 100 grains each, taken from the filled grain fraction.

Primary statistical analysis was performed by analysis of variance of each trial (control and stressed) separately, considering the trials to be laid out as randomized blocks.
Correlations and regressions were calculated for each trial separately on genotype means for each variate.

\section{RESULTS AND DISCUSSION}

In 1991, the sowings which were the first to flower had good water availability to complete their growth and development and to give good yield. These sowings were taken to constitute the control trial. In contrast, the sowings which were last to flower experienced water shortage during the period of panicle emergence and early grain filling. These sowings were kept without irrigation for 18 days. The dates of $50 \%$ flowering of the first and last genotype to flower, and the mean date of flowering of all genotypes are given in Table 1 . Soil water was depleted slowly and before it was replenished through sprinkler irrigation at the end of the stress period, the plants had attained water potentials varying between -1.1 and -1.8 MPa, with a mean value of -1.4 MPa.

In 1992, the control and the stressed plots were of the same sowing date and differed only slightly in date of flowering (Table 1). After 23 days without rain, plots were visibly stressed and leaf water potentials, in the last day of stress imposition, ranged from -1.2 to -2.2 $\mathrm{MPa}$, with an average of -1.8 $\mathrm{MPa}$.

In the 1994 trials, the matched sowing of the genotypes flowered over a ten-day period, starting seven days after stress imposition in the stressed trial, and the mean date of flowering was attained in the thirteenth day of a stress imposition period of 22 days (Table 1). Due to residual rains $(13,3 \mathrm{~mm})$ and cloudy weather, mean leaf water potential in the stressed plots reached a mean value of -1.31 MPa on the last day of stress imposition, considerably higher (less stressed) than in the previous years.

TABLE 1. Dates of beginning and end of stress treatment and dates of flowering, for the control and stressed trials, in three years of field experiments.

\begin{tabular}{|c|c|c|c|c|c|c|}
\hline \multirow[t]{2}{*}{ Variable } & \multicolumn{2}{|c|}{1991} & \multicolumn{2}{|c|}{1992} & \multicolumn{2}{|c|}{1994} \\
\hline & Stressed & Control $^{1}$ & Stressed & Control & Stressed & Control \\
\hline Beginning of stress & 20 Apr. & - & 5 May & - & 4 May & - \\
\hline Flowering of earliest genotype & 19 Apr. & 10 Apr. & 11 May & 11 May & 10 May & 17 May \\
\hline Mean date of flowering & $26 \mathrm{Apr}$. & 13 Apr. & 15 May & 15 May & 16 May & 20 May \\
\hline Flowering of latest genotype & 1 May & 16 Apr. & 19 May & 18 May & 23 May & 27 May \\
\hline End of stress & 7 May & - & 27 May & - & 25 May & - \\
\hline
\end{tabular}


Due to late sowing, the yield of all experiments was below the potential, which is around 4.5 tons/ha, for traditional upland rice plant type ( $\mathrm{Pi}$ nheiro \& Guimarães, 1990). Nevertheless, both in the 1991 and 1994 trials, control yield fell within the average yield in the region, of 1.4 ton/ha, while it was greater than that in 1992 (Table 2).

Except for1994, mean yields, as expected, were greater in the irrigated control than in the stressed trials (Table 2). Stress intensity was most severe in the 1992 trial, resulting in a $42 \%$ of yield loss, whereas the yield loss in 1991 was of only $20 \%$. In 1994, yields from the irrigated trial were low, reflecting the poor growth of the plants on this trial site. This trial was sown on soil which had been cropped with rice in the previous season; such sequential cropping was later verified to induce a process of autotoxicity (Silveira et al., 1998) which is likely to have been the main reason for the poor yield from this irrigated trial.
Plant growth in the stressed trial, by contrast, was normal, and yields were considered to have been depressed by the drought treatment, and not by other unquantified features.

The average reduction in yield over the three years was $22 \%$. It should be remembered that each year the control and stressed trials were on different, though adjacent land, so in any one year the estimate of the effect of drought on yield was confounded with trial site.

In each year, drought reduced spikelet fertility, the average reduction over the three years being $20 \%$ (spikelet fertility in irrigated trials $71.6 \%$, in stressed trials $57.5 \%$ ). Thus the percentage reduction in yield was virtually the same as the percentage reduction in spikelet fertility. Drought also reduced $\Delta \mathrm{s}$ but generally had less effect on the $\Delta$ of the bulk plant tissues (Table 2), as previously reported (Scartazza et al., 1998).

TABLE 2. Means of the given characters in rice genotypes, in the control and stressed trials, in three years of field experiments ${ }^{1}$.

\begin{tabular}{|c|c|c|c|c|c|c|}
\hline \multirow[t]{2}{*}{ Variable } & \multicolumn{2}{|c|}{1991} & \multicolumn{2}{|c|}{1992} & \multicolumn{2}{|c|}{1994} \\
\hline & Control & Stressed & Control & Stressed & Control & Stressed \\
\hline Yield $\left(\mathrm{g} \mathrm{m}^{-2}\right)$ & $\begin{array}{l}232^{\mathrm{ns}} \\
(26)\end{array}$ & $\begin{array}{c}188 * * * \\
(42)\end{array}$ & $\begin{array}{c}260 * * \\
(45)\end{array}$ & $\begin{array}{c}150 * * * \\
(65)\end{array}$ & $\begin{array}{c}152 * * * \\
(30)\end{array}$ & $\begin{array}{c}152^{* * * *} \\
(48)\end{array}$ \\
\hline Spikelet fertility (\%) & $\begin{array}{c}81 * * * \\
(3.6)\end{array}$ & $\begin{array}{l}67 * * * \\
(11.7)\end{array}$ & $\begin{array}{c}67 * * \\
(13.1)\end{array}$ & $\begin{array}{l}46 * * \\
(18.1)\end{array}$ & $\begin{array}{c}67 * * \\
(10.3)\end{array}$ & $\begin{array}{c}60 \\
(14.6)\end{array}$ \\
\hline Mass of 100 grains (g) & $\begin{array}{c}2.73 * * * \\
(0.17)\end{array}$ & $\begin{array}{c}2.80 * * * \\
(2.80)\end{array}$ & $\begin{array}{l}2.62 * * \\
(0.43)\end{array}$ & $\begin{array}{l}2.40 * * \\
(0.25)\end{array}$ & $\begin{array}{c}2.56 * * * \\
(0.30)\end{array}$ & $\begin{array}{c}2.55 \\
(0.30)\end{array}$ \\
\hline$\Delta \mathrm{s} \quad(\%)$ & $\begin{array}{c}18.57 * * \\
(0.44)\end{array}$ & $\begin{array}{c}16.28 * * * \\
(0.38)\end{array}$ & $\begin{array}{c}16.64 * * * \\
(0.60)\end{array}$ & $\begin{array}{c}16.02 * * * \\
(0.55)\end{array}$ & $\begin{array}{c}17.22 * * * \\
(0.52)\end{array}$ & $\begin{array}{l}15.94 \\
(0.46)\end{array}$ \\
\hline$\Delta \mathrm{l}\left({ }^{\circ} \%_{00}\right)$ & - & - & $\begin{array}{c}19.37 * * * \\
(0.56)\end{array}$ & $\begin{array}{c}19.04 * * * \\
(0.44)\end{array}$ & - & $19.64^{\mathrm{ns}}$ \\
\hline$\Delta \mathrm{p}\left({ }^{\circ} / 00\right)$ & $\begin{array}{c}18.90 * * * \\
(0.46)\end{array}$ & $\begin{array}{c}17.84^{\mathrm{ns}} \\
(0.30)\end{array}$ & - & - & $\begin{array}{c}18.78^{\mathrm{ns}} \\
(0.32)\end{array}$ & $\begin{array}{c}17.96^{\mathrm{ns}} \\
(0.31)\end{array}$ \\
\hline$\Delta \mathrm{g}\left({ }_{00}\right)$ & $\begin{array}{c}18.93 * * * \\
(0.47)\end{array}$ & $\begin{array}{c}18.32 * * * \\
(0.43)\end{array}$ & $\begin{array}{c}18.20 * * * \\
(0.46)\end{array}$ & $\begin{array}{c}17.47 * * * \\
(0.55)\end{array}$ & $\begin{array}{l}18.64 * \\
(0.41)\end{array}$ & $\begin{array}{c}18.10^{\mathrm{ns}} \\
(0.34)\end{array}$ \\
\hline dsif (number) & $\begin{array}{l}12.9 \\
(1.6)\end{array}$ & $\begin{array}{l}26.1 \\
(3.7)\end{array}$ & $\begin{array}{l}15.1 \\
(2.1)\end{array}$ & $\begin{array}{l}14.9 \\
(2.4)\end{array}$ & $\begin{array}{l}19.6 \\
(2.3)\end{array}$ & $\begin{array}{l}16.2 \\
(3.0)\end{array}$ \\
\hline
\end{tabular}

${ }^{1}$ Numbers inside brackets are phenotypic standard deviation; $\Delta \mathrm{s}$ : carbon isotope discrimination of sugars extracted from the uppermost internode at the end of the stress period; $\Delta \mathrm{l}$ : carbon isotope discrimination of flag leaves at the end of the stress period; $\Delta \mathrm{p}$ : carbon isotope discrimination of uppermost internodes; $\Delta \mathrm{g}$ : carbon isotope discrimination of grains; both at harvest; dsif: days from stress imposition to $50 \%$ panicle emergence.

ns,${ }^{* * *}$ and ${ }^{* * *}$ Non-significant and significant at $5 \%, 1 \%$ and $0,1 \%$, respectively, by the $\mathrm{F}$ test. 
Table 2 gives the means and phenotypic standard deviations (psd) of the main variates. The psd of a variate is the square root of the variance of the genotype mean squares. In the context of the present work, it is more meaningful than the coefficient of variation which is $\mathrm{psd} / \mathrm{mean}$ expressed as a percentage. Table 3 shows that the average correlation coefficient between grain yield and spikelet fertility was +0.715 in the stressed trials but +0.403 in the irrigated ones. Table 3 also shows that, among genotypes, yield was negatively correlated with $\Delta \mathrm{s}$ at the end of the drought period. This association was also evident, though weaker, in the irrigated trials. Yield was also, but generally more weakly, negatively associated with $\Delta \mathrm{g}$.

Even though sowing was phased in the attempt to synchronize date of flowering of the genotypes, there was some variation. The genotypes which were the earliest to flower in relation to the drought imposition period, tended to be of high yielding. Thus the association between grain yield and $\Delta \mathrm{s}$ was likely to have been distorted by the association between yield and the number of days from stress imposition to flowering (dsif). To allow this, a multiple regression of $\Delta \mathrm{s}$ and dsif on yield was computed for each trial.
The results (Table 4) showed that the negative association between yield and $\Delta \mathrm{s}$ was maintained, though it was only significant in the stressed trial in 1991. Table 4 also shows that for the stressed trials, the coefficient for dsif and yield was itself significant, indicating the importance of the time of stress imposition in relation to flowering: those genotypes which reached flowering the soonest after stress imposition suffered the least reduction in yield. Statistical analysis was also carried out to test whether genotypes which had a long growth cycle (a long period between sowing and flowering) and which may have been expected to be larger at the time of stress imposition, and hence to lose water more rapidly, were more affected by the stress imposed. The results showed no relationship of the size of the growth cycle and any other variable measured. Hence, in these trials, date of sowing and duration of life cycle were not factors which affected the interpretation of the relationship between yield, $\Delta \mathrm{s}$ and dsif.

Analysis of variance of all the data for the six genotypes common to all trials (Table 5) showed that there were significant differences among genotypes for all variates, and that, except for $\Delta \mathrm{s}$, genotypes

TABLE 3. Simple correlation coefficients between the given characters, for the control and stressed trials, in three years of field experiments ${ }^{1}$.

\begin{tabular}{|c|c|c|c|c|c|c|c|c|}
\hline \multirow{2}{*}{$\begin{array}{l}\text { Correlated } \\
\text { characters }\end{array}$} & \multicolumn{2}{|c|}{1991} & \multicolumn{2}{|c|}{1992} & \multicolumn{2}{|c|}{1994} & \multicolumn{2}{|c|}{ Mean } \\
\hline & Control & Stressed & $\overline{\text { Control }}$ & Stressed & Control & Stressed & $\overline{\text { Control }}$ & Stressed \\
\hline Yield and $\Delta \mathrm{s}$ & -0.162 & -0.337 & -0.548 & -0.416 & -0.111 & -0.168 & -0.273 & -0.307 \\
\hline Yield and $\Delta \mathrm{l}$ & - & - & -0.089 & -0.214 & - & +0.182 & - & - \\
\hline Yield and $\Delta \mathrm{p}$ & -0.355 & -0.212 & - & - & -0.111 & +0.041 & - & - \\
\hline Yield and $\Delta \mathrm{g}$ & -0.362 & -0.393 & -0.247 & +0.207 & -0.274 & -0.108 & -0.294 & -0.098 \\
\hline Yield and sf & +0.288 & +0.491 & +0.339 & +0.842 & +0.579 & +0.811 & +0.403 & +0.715 \\
\hline Yield and dsif & -0.269 & -0.271 & -0.274 & -0.541 & +0.049 & -0.330 & -0.171 & -0.380 \\
\hline sf and $\Delta s$ & -0.209 & +0.222 & -0.577 & -0.482 & +0.047 & -0.040 & -0.246 & -0.100 \\
\hline dsif and $\Delta \mathrm{s}$ & -0.235 & -0.520 & +0.384 & +0.084 & -0.256 & -0.318 & -0.052 & -0.251 \\
\hline Degrees of freedom & 18 & 18 & 16 & 16 & 22 & 22 & 43 & 43 \\
\hline $\mathrm{r}$ & 0.444 & 0.444 & 0.468 & 0.468 & 0.404 & 0.404 & 0.288 & 0.288 \\
\hline
\end{tabular}

${ }^{1} \Delta \mathrm{s}$ : carbon isotope discrimination of sugars extracted from the uppermost internode at the end of the stress period; $\Delta \mathrm{l}$ : carbon isotope discrimination of flag leaves at the end of the stress period; $\Delta \mathrm{p}$ : carbon isotope discrimination of uppermost internodes; $\Delta \mathrm{g}$ : carbon isotope discrimination of grains; both at harvest; dsif: days from stress imposition to $50 \%$ panicle emergence; sf: spikelet fertility; r: value of correlation coefficien at $5 \%$ probability. 
TABLE 4. Multiple regression coefficients of carbon isotope discrimination of soluble sugars extracted from the uppermost internode $(\Delta s)$ and number of days from stress imposition and flowering (dsif) on grain yield and spikelet fertility, for the control and stressed trials, in three years of field experiments ${ }^{1}$.

\begin{tabular}{|c|c|c|c|c|c|c|c|c|c|c|}
\hline \multirow[t]{3}{*}{ Year } & \multicolumn{5}{|c|}{ Stressed trials } & \multicolumn{5}{|c|}{ Control trials } \\
\hline & \multicolumn{2}{|c|}{$\Delta \mathrm{s}$} & \multicolumn{3}{|c|}{ dsif } & \multicolumn{2}{|c|}{$\Delta s$} & \multicolumn{3}{|c|}{ dsif } \\
\hline & $\mathrm{b}$ & s.e. & $\mathrm{b}$ & s.e. & \%v.a.f. & $\mathrm{b}$ & s.e. & $\mathrm{b}$ & s.e. & \%va.f. \\
\hline & \multicolumn{10}{|c|}{ Grain yield } \\
\hline 1991 & -63.60 & 31.10 & -5.66 & 3.29 & 17.5 & -13.50 & 14.5 & -5.78 & 4.57 & 0.1 \\
\hline 1992 & -44.80 & 23.40 & -13.97 & 5.36 & 35.5 & -38.80 & 17.2 & -2.18 & 4.83 & 21.7 \\
\hline 1994 & -29.20 & 19.90 & -6.81 & 3.30 & 11.5 & -6.00 & 12.6 & 0.28 & 2.89 & 0.0 \\
\hline & \multicolumn{10}{|c|}{ Spikelet fertility } \\
\hline 1991 & -5.74 & 5.38 & -2.78 & 0.56 & 66.0 & -2.40 & 1.99 & -0.97 & 0.62 & 6.8 \\
\hline 1992 & -13.57 & 6.68 & -3.41 & 1.53 & 31.8 & -12.05 & 4.87 & -0.46 & 1.37 & 24.9 \\
\hline 1994 & -5.90 & 5.96 & -2.46 & 0.99 & 15.6 & 0.00 & 2.89 & -0.81 & 0.99 & 0.0 \\
\hline
\end{tabular}

${ }^{1}$ b: multiple regression coefficient; s.e.: standard error; \%v.a.f.: percentage variation accounted for by the given regression.

TABLE 5. Mean squares from the analysis of variance across years for grain yield, spikelet fertility, carbon isotope discrimination of grains $(\Delta \mathrm{g})$ or of soluble sugars extracted from the uppermost internode $(\Delta s)$, for the six rice genotypes common to all trials.

\begin{tabular}{lccccc}
\hline Item & Degrees of freedom & Grain yield & Spikelet fertility & $\Delta \mathrm{g}$ & $\Delta \mathrm{s}$ \\
\hline Genotype (G) & 5 & 1,943 & 275.3 & 0.4691 & 0.4153 \\
Year (Y) & 2 & 14,193 & 353.2 & 2.0661 & 4.9475 \\
Water (W) & 1 & 12,564 & 541.2 & 1.0927 & 15.0973 \\
G x Y & 10 & 1,560 & 28.8 & 0.1910 & 0.0809 \\
G x W & 5 & 1,299 & 55.3 & 0.2016 & 0.0261 \\
G x Y x W & 10 & 369 & 20.6 & 0.0438 & 0.0702 \\
Error & 121 & 317 & 17.4 & 0.0465 & 0.0750 \\
\hline
\end{tabular}

varied in their response to drought, as judged by the significance of the genotype $\mathrm{x}$ irrigation treatment interaction term.

In all experiments, drought reduced $\Delta s$, the $\Delta$ of sugars extracted from the stem uppermost internode at the end of the drought period. As noted earlier, these sugars can represent part of the carbon assimilated during the drought period. The $\Delta$ of these sugars reflects the assimilation-weighted value of the ratio of intercellular and atmospheric partial pressures of $\mathrm{CO}_{2}$ (pi/pa) when the contributing carbon was assimilated during the drought period (Brugnoli et al., 1988, 1998).

The coefficients of the number of days from stress imposition to flowering (dsif) term in the multiple regressions (Table 4) were negative (except for one, non-significant exception). This result implies that genotypes which flowered soonest after stress imposition gave greater yields for a given $\Delta \mathrm{s}$ than later flowering ones. All genotypes in a given trial would have experienced the same duration of drought, but the early flowering ones would likely have been less stressed during the critical early phase of panicle emergence than later flowering ones, because plant water stress would have become progressively more severe with increasing time from the start of the drought period. If this interpretation is correct, it suggests that there is a 'window' during the period of panicle emergence when spikelet fertility is the most sensitive to water stress, before and after which its sensitivity is considerably less. This finding is consistent with the reports of Batchelor \& Roberts (1983) and O'Toole et al. (1984) that the diffusive conductance of panicles to water loss is very high 
during early panicle emergence. Pinheiro (1989) found that spikelets were most drought-sensitive when $3-9 \mathrm{~cm}$ of the panicle had emerged from the flag leaf sheath. Panicles within the flag leaf sheath or those which had emerged earlier had a greater spikelet fertility. It is possible that this effect of drought was mediated by plant water status per se (including possible hormonal effects), or through effects on the availability of carbohydrates, either mobilized from storage or derived from current photosynthesis. In either case, genotypes which flowered early in the period of stress would have been likely to escape the worst effects of drought. Indeed, for the stressed trials, the importance of the spikelet fertility term in the multiple regressions (Table 4) was greater than that of the $\Delta$ s term. It is not possible from the present results to determine whether or not there was variation among genotypes which were at exactly the same stage of panicle emergence at the time of stress imposition in their panicle water loss and consequent sensitivity to drought. To make such an assessment, near-isogenic lines would need to be compared.

As expected, drought reduced $\Delta \mathrm{p}$ and $\Delta \mathrm{g}$, presumably because some growth in structural dry matter of the uppermost internode was occurring during the drought period, and soluble sugars accumulated during panicle emergence made some contribution to grain carbon. In contrast, drought had little effect on $\Delta \mathrm{l}$, probably because the leaves were fully grown when sampled.

Possible explanations of the negative correlation between $\Delta \mathrm{s}$ and yield include increased water use efficiency, which may be beneficial for fertility and grain yield. Low $\Delta \mathrm{s}$ implies a low ratio of intercellular and atmospheric $\mathrm{CO}_{2}$ (pi/pa) and probably low stomatal conductance during the period when sugars are accumulating in uppermost internodes. Alternatively, it could imply a high carboxylation capacity, but this is a most unlikely effect of drought. Low pi/pa implies a high leaf level water use efficiency reflected in low $\Delta$ of the carbon formed from current photosynthesis, including that of uppermost internode sugars.

\section{CONCLUSIONS}

1. Carbon isotope discrimination of soluble sugars extracted from the stem uppermost internode $(\Delta s)$ is not a sufficiently reliable indicator of drought resistance among rice genotypes to be useful as a screening test in breeding programs.

2. The timing of drought occurrence in relation to panicle emergence and flowering appeared to be a more important cause of yield variation among genotypes than variation in $\Delta \mathrm{s}$.

\section{ACKNOWLEDGEMENTS}

To the European Commission D.G. XII, who supported this work-Contract number TS3 CT930200; to Enrico Brugnoli for helpful discussions during the course of this work.

\section{REFERENCES}

AUSTIN, R.B.; EDRICH, J.A.; FORD, M.A.; BLACKWELL, R.D. The fate of the dry matter, carbohydrates and ${ }^{14} \mathrm{C}$ lost from the leaves and stems of wheat during grain filling. Annals of Botany, London, v.41, p.1309-1321, 1977.

AUSTIN, R.B.; MORGAN, C.L.; FORD, M.A.; BLACKWELL, R.D. Contributions to grain yield from pre-anthesis assimilation in tall and dwarf barley phenotypes in two contrasting seasons. Annals of Botany, London, v.45, p.309-319, 1980.

BATCHELOR, C.H.; ROBERTS, J. Evaporation from the irrigation water, foliage and panicles of paddy rice in North-East Sri Lanka. Agricultural Meteorology, Amsterdam, v.29, n.1, p.11-26, 1983.

BRUGNOLI, E.; FARQUHAR, G.D. Photosynthetic fractionation of carbon isotopes. In: LEEGOOD, R.C.; SHARKEY, T.D.; CAEMMERER, S. von. (Ed.). Photosynthesis: physiology and metabolism, advances in photosynthesis. The Netherlands : Kluwer Academic, 2000. p.399-434.

BRUGNOLI, E.; HUBICK, K.T.; CAEMMERER, S. von; WONG, S.C.; FARQUHAR, G.D. Correlation between the carbon isotope discrimination in leaf starch and sugars of $\mathrm{C}_{3}$ plants and the ratio of intercellular and atmospheric partial pressures of carbon dioxide. Plant Physiology, Rockville, v.88, n.4, p.1418-1424, 1988.

BRUGNOLI, E.; SCARTAZZA, A.; LAUTERI, M.; MONTEVERDI, M.C.; MÁGUAS, C. Carbon 
isotope discrimination in structural and nonstructural carbohydrates in relation to productivity and adaptation to unfavorable conditions. In: GRIFFITHS, H. (Ed.). Stable isotopes: integration of biological, ecological and geochemical processes. Oxford: BIOS Scientific, 1998. p.133-146.

CONDON, A.G.; RICHARDS, R.A.; FARQUHAR, G.D. Carbon isotope discrimination is positively correlated with grain yield and dry matter production in field grown-wheat. Crop Science, Madison, v.27, n.5, p.996-1001, 1987.

CRAUFURD, P.Q.; AUSTIN, R.B.; ACEVEDO, E.; HALL, M.A. Carbon isotope discrimination and grain-yield in barley. Field Crops Research, Amsterdam, v.27, n.4, p.301-313, 1991.

DINGKUHN, M.; FARQUHAR, G.D.; DE DATTA, S.K.; O'TOOLE, J.C. Discrimination of ${ }^{13} \mathrm{C}$ among rice genotypes having different water use efficiencies. Australian Journal of Agricultural Research, Collingwood, v.42, p.1123-1131, 1991.

EHDAIE, B.; HALL, A.E.; FARQUHAR, G.D.; NGUYEN, H.T.; WAINES J.G. Water-use efficiency and carbon isotope discrimination in wheat. Crop Science, Madison, v.31, n.5, p.1282-1288, 1991.

EKANAYAKE, I.J.; DE DATTA, S.K.; STEPONKUS, P.L. Spikelet sterility and flowering response of rice to water stress at anthesis. Annals of Botany, London, v.63, p.257-264, 1989.

EKANAYAKE, I.J.; STEPONKUS, P.L.; DE DATTA, S.K. Sensitivity of pollination to water deficits at anthesis in upland rice. Crop Science, Madison, v.30, n.2, p.310-315, 1990 .

FARQUHAR, G.D.; EHLERINGER, J.R.; HUBICK, K.T. Carbon isotope discrimination and photosynthesis. Annual Review of Plant Physiology and Plant Molecular Biology, Palo Alto, v.40, p.503-537, 1989.

FARQUHAR, G.D.; RICHARDS, R.A. Isotopic composition of plant carbon correlates with wateruse efficiency of wheat genotypes. Australian Journal of Plant Physiology, Collingwood, v.11, n.6, p.539-552, 1984

HALL, A.E.; RICHARDS, R.A.; CONDON, A.G.; WRIGHT, G.C.; FARQUHAR, G.D. Carbon isotope discrimination and plant breeding. Plant Breeding Reviews, New York, v.12, p.81-113, 1994.
HSIAO, T.C. The soil plant atmosphere continuum in relation to drought and crop production. In: INTERNATIONAL RICE RESEARCH INSTITUTE (Los Baños, Filipinas). Drought resistance in crops with emphasis on rice. Los Baños, 1982. p.39-52.

NGUGI, E.C.K.; AUSTIN, R.B.; GALWEY, N.W.; HALL, M.A. Associations between grain yield and carbon isotope discrimination in cowpea. European Journal of Agronomy, Amsterdam, v.5, n.1/2, p.917, 1996.

O'TOOLE, J.C.; HSIAO, T.C.; NAMUCO, O.S. Panicle water relations during water stress. Plant Science Letters, Limerick, v.33, n.2, p.137-143, 1984.

O'TOOLE, J.C.; NAMUCO, O.S. Role of panicle exsertion in water stress induced sterility. Crop Science, Madison, v.23, n.6, p.1093-1097, 1983.

PINHEIRO, B. da S. Estudo das relações hídricas durante o processo de emissão de panículas e antese do arroz de sequeiro (Oryza sativa L.). Campinas : USP, 1989. 176p. Tese de Doutorado.

PINHEIRO, B. da S.; GUIMARÃES, E.P. Índice de área foliar e produtividade do arroz de sequeiro. I. Níveis limitantes. Pesquisa Agropecuária Brasileira, Brasília, v.25, n.6, p.863-872, jun. 1990.

PINHEIRO, B. da S.; STEINMETZ, S.; STONE, L.F.; GUIMARÃES, E.P. Tipo de planta, regime hídrico e produtividade do arroz de sequeiro. Pesquisa Agropecuária Brasileira, Brasília, v.20, n.1, p.8795, jan. 1985.

SAYRE, K.D.; ACEVEDO, E.; AUSTIN, R.B. Carbon isotope discrimination and grain yield for three bread wheat germplasm groups grown at different levels of water stress. Field Crops Research, Amsterdam, v.41, n.1, p.45-54, 1995.

SCARTAZZA, A.; LAUTERI, M; GUIDO, M.C.; BRUGNOLI, E. Carbon isotope discrimination in leaf and stem sugars, water use efficiency and mesophyll conductance during different developmental stages in rice subjected to drought. Australian Journal of Plant Physiology, Collingwood, v.25, p.489-498, 1998.

SILVEIRA，P.M. da; ZIMMERMANN，F.J.P.; AMARAL, A.M. do. Efeito da sucessão de cultura e do preparo do solo sobre o rendimento do arroz de sequeiro. Pesquisa Agropecuária Brasileira. Brasília, v.33, n.6, p.885-890, jun. 1998. 